\title{
COVID-19 on the Telecommunications Industry Stock Market Performances: An Event-Study Approach
}

\section{Pratita Garnis Ariantika ${ }^{*}$, Arthik Davianti²}

${ }^{1,2}$ Satya Wacana Christian University, Salatiga, Indonesia

\section{ART ICLE I N F O}

Article history:

Received May 01, 2021

Revised May 03, 2021

Accepted June 01, 2021

Available online June 25, 2021

Keywords:

Abnormal Returns, Event

Studies, Telecommunications Sector

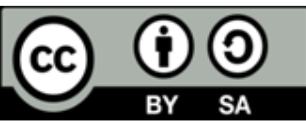

This is an open access article under the CC BY-SA license.

Copyright (@) 2021 by Author. Published by Universitas Pendidikan Ganesha.

\begin{abstract}
A B S T R A C T
Covid-19's impact on the global economy is unclear. The stock market has responded with dramatic moves around the world. This study aims to analyze the quality of knowledge of the COVID-19 pandemic events regarding the performance of the Indonesian stock market as seen from the average abnormal return before and after the first case of COVID-19 Indonesia on March 2, 2020. The research design used in this study is an event study. The three samples used in this study are companies engaged in the telecommunications sub-sector on the Indonesia Stock Exchange. The sampling technique used in this research is purposive sampling. The study focused on a window period of 15 days before and 15 days after the event date. Hypothesis testing was carried out using the paired sample t-test on data with a typical distribution and the one-sample Wilcoxon signed-ranked test on data that were not normally distributed. The results obtained are that stocks react positively but not significantly to the announcement of the first case in Indonesia using an event study research design. There is a significant difference in abnormal returns before and after the first case of COVID-19 patients in Indonesia was announced.
\end{abstract}

\section{INTRODUCTION}

Coronavirus disease 2019 (COVID-19) is characterized as a severe contagious disease that attacks the respiratory system, first detected amid epidemic respiratory diseases in December 2019 in Wuhan City, China (Hincal \& Alsaadi, 2021; H. Liu et al., 2020). On January 30, 2020, the World Health Organization (WHO) released a global alert about the COVID-19. The WHO announced the COVID-19 global pandemic on March 11, 2020. The Indonesian government announced COVID-19 cases on March 2, 2020 (Aji, 2020; Ambarita, 2021; Putria et al., 2020). Three months later, the Ministry of Health of the Republic of Indonesia announced that 28,818 people confirmed COVID-19.

Consumers, businesses, and communities worldwide are concerned about the coronavirus (COVID19) outbreak, causing widespread fear and economic hardship (Hincal \& Alsaadi, 2021; Shah et al., 2020). The situation is rapidly shifting, with far-reaching consequences. The COVID-19 pandemic has a detrimental effect on people's health and the economies of countries worldwide, including Indonesia (Alonderienè \& Suchotina, 2017; Sohrabi et al., 2020). This pandemic had forced many countries to restrict their citizens' mobility, which impacted various major sectors, particularly the country's economic activities (Mpungose, 2021). Industry sectors that were negatively affected by this pandemic were tourism, aviation, food and beverage industries, and industrial retail. Various policies issued, 'social distancing,' and 'work-from-home (WFH)' became the focus in handling this disease. The 'social distancing' policy encouraged the increased use of telecommunications operators' internet data by $5 \%$ to $10 \%$. Further, the Indonesian Minister of Finance, Sri Mulyani, claims that COVID-19 harms all countries, but not all sectors experience it. Several business sectors share profits amid the COVID-19 pandemic, including the textile industry and products from textiles, chemicals, pharmaceuticals, medical tools, electronics, telecommunications services, and logistics services.

The telecommunications service industry provider is a profitable sector during this pandemic, despite an insignificant prediction. However, shares in the telecommunications sector have become investors' targets because the stakes are still considered worth buying and safe (Shahzad et al., 2021; Stalmachova \& Strenitzerova, 2021). After all, the prospects will continue to grow in line with the increasing demand for internet access. Market conditions continue to grow; the telecommunications sector is 
considered a driver of economic growth in Indonesia amid this pandemic (Gandasari \& Dwidienawati, 2020).

Moreover, the global economy's impact on the economy was not yet clear, the stock market responded with dramatic movements around the world (Ali et al., 2021; Lyócsa \& Molnár, 2020). The WHO and the COVID-19 Handling Task Force in Indonesia role as mediators for delivering pandemic risk information to investors. An event will influence investors' sentiment. This COVID-19 pandemic event shaped investors' sentiment and has a tremendous influence on the stock market (Dey et al., 2021; Lyócsa et al., 2020). During a pandemic, information reported in the news, such as information regarding an increase in the number of cases, will affect stock market conditions, perhaps causing a drop in stock prices. The price volatility and stock trading activities could be influenced by relevant information on an event (Haryanto, 2020; Q. Liu et al., 2020; Wibowo \& Darmanto, 2019).

The COVID-19 pandemic is categorized as a macro that affects all country sectors, including the stock market (Indrawati et al., 2020; Scherf et al., 2021). Therefore, the relevant information is considered available in this one of the macro events. Hence, it is not surprising that this event drives a concern to discuss the impact of COVID-19 on stock price movements and volume-trading activities on the Indonesia Stock Exchange, as the latest information related to the pandemic is highly anticipated. Understanding the dynamics of the pandemic is critical for investors to make investment decisions. The stock market performance could be significantly influenced by the investors' sentiment on certain events. Optimistically, investors can behave if there is an upward trend in the market and a low risk (Engelhardt et al., 2021; Yousfi et al., 2021). Investors will tend to act relatively pessimistically then lead the market trends down (Ahmad et al., 2021; Ben-Ahmed et al., 2021). Therefore, it is suspected that the investors would choose to wait for a market revival in making investment decisions.

The COVID-19 pandemic can be classified as a significant event since the whole world can feel its impact (Huang, 2020; Simamora, 2020; Sintema, 2020). Many industries were affected primarily by the government's declaring 'social-distancing \& work-from-home scheme.' Telecommunications is one area that remains resilient amid the pandemic. Significant events might significantly affect the returns on the stock markets (Ben-Ahmed et al., 2021; Matos et al., 2021). Investors are 'glancing' at shares in the telecommunications sub-sector that will be collected, given the valuation is also quite attractive. The community's desire for a digital lifestyle with Internet data connectivity helped hoist the performance of telecommunications issuers. The stock market is strongly influenced by various changes and events with investors' information content.

Previous research examined the impact of financial performance on stock prices on COVID-19 (AlAli, 2020; Asmirantho \& Somantri, 2017; Baker et al., 2020; Bash, 2020). Meanwhile other research examines stock market reactions to political events (Ratnaningsih \& Widanaputra, 2019). Hence, this study would investigate similar research on how the COVID-19 outbreak affects the telecommunications industry performance based on the Indonesia setting. This study concentrates on the 'fight and aftermath' of the COVID-19 crisis outbreak, particularly on understanding its influences on the stock performances. An event study approach is applied in this research, aiming to analyze the knowledge quality of the COVID-19 pandemic event regarding the Indonesian stock market's performance. The examination includes the telecommunication sector listed in Indonesia Stock Exchanges to present a more comprehensive outlook on the outbreak's economic impacts on the country's economy. This research will investigate the stock market reaction to the COVID-19 pandemic event and prepare the business for an analogous pandemic.

\section{METHODS}

The research design used in this study is an event study. This study describes the problem systematically and factually regarding the effects of COVID-19 on the stock market performance in the Indonesian telecommunications industry. A quantitative data method was used to carry out this research with data collected using secondary data, data from financial reports accessed on the official website Indonesia Stock Exchange website (IDX) and Yahoo Finance website. Generally, the data are in historical reports published by the Indonesia Stock Exchange website (IDX) and Yahoo Finance. The data collected includes; the names of listed companies as samples are telecommunications companies during the observation period, daily stock market prices during the observation period, and the daily Composite Stock Price Index (IHSG) during the observation period.

The observation period is divided into two in the event study, especially the event and estimation periods. The event period is when the event will be investigated, while the predicted duration is before the event. In this study, the event period was 61 days, 15 days before the first COVID-19 case was announced in Indonesia ( $t-15)$ and 15 days after the ranking announcement $(t+15)$. The population used in this study is the sub-sectoral stocks of telecommunications that are consistently listed in the Indonesia Stock Exchange 
over the study period. In this study, purposive sampling is applied. The sample criteria used stocks listed on the Indonesia Stock Exchange and included in the telecommunication sub-sector most actively traded during the COVID-19 pandemic. Therefore, the investors' reaction to the pandemic situations is expected to be expressed through the change in stock prices. The parameters are modified to generate three sample data of the telecommunications sector listed in the Indonesia Stock Exchange for the question studied.

Tabel 1. Telecommunication Companies Listed on Indonesia Stock Exchange

\begin{tabular}{clcc}
\hline No & \multicolumn{1}{c}{ Company's Name } & Stock Code & \multicolumn{1}{c}{ Sector/Sub-sector } \\
\hline 1 & PT XL Axiata Tbk & EXCL & Service Industry / Telecommunications \\
2 & PT Indosat Tbk & ISAT & Service Industry / Telecommunications \\
3 & PT Telekomunikasi Indonesia & TLKM & Service Industry / Telecommunications \\
\hline
\end{tabular}

This study's analytical technique is the parametric analysis test, namely the paired sample and one sample t-test using Microsoft Excel and SPSS. The statistical parametric test includes a normal distribution of the available resources. Therefore, a normality test is needed. The normality test is carried out with the Shapiro-Wilk test. After the data is normally distributed, then the paired sample, one sample t-test hypothesis is tested. If the data used are not normally distributed, the one-sample Wilcoxon signed-ranked test will be used. Paired tests are used because, in this study, two groups of returns are tested, namely returns before and after the COVID-19 event of members of the telecommunications industry sub-sector shares listed at the Indonesia Stock Exchange.

\section{RESULTS AND DISCUSSIONS}

\section{Results}

A sample of data collected over a particular observation period from telecommunications companies listed on the Indonesia Stock Exchange (IDX) was used in this analysis. The sampling of the data used is limited to a certain number by using the purposive sampling method. There were three telecommunications companies most actively traded during the event period and match the criteria. By selecting these companies from sectors that represent the most significant market capitalization, it can be inferred whether there are abnormal returns on the sectoral indices due to COVID-19 or not. An event study test used the window period model (event-window) on this study to prove the stock market reaction whether there is an abnormal return on the event.

Hypothesis I stated that positive abnormal returns were occurring over the announcement of the beginning of COVID-19 in Indonesia. The abnormal return is more strong proof of how and why the market responds to info. If there is indeed a positive abnormal return, the market reacts positively to the information. In contrast, if there is a positive abnormal return, the market reacts positively but not significant to the relevant evidence (Dian et al., 2019). This study conducted a normality test using the Shapiro-Wilk test and one-sample Wilcoxon signed-rank test. Before and after the event, the research data had a value of more than 0.05 . Therefore, it was concluded that data were normally distributed. For the Telecommunication sectoral, abnormal returns were only found on the days -13 event window, which indicates the need for a longer period to be affected by COVID-19. By using event studies, different event dates might give different results, which means that it takes time for these sectors to be affected by pandemic situations for PT. XL Axiata Tbk, abnormal Return was found on day -1 with sig. value 0.071 and day +14 with a sig. value 0.112 . PT. Indosat Tbk experienced an abnormal return on day -11 , day -9 , day -0 , and day +5 with a sig. value $0.066,0.055,0.064$, and 0.072 . Meanwhile, the abnormal Return at PT. Telekomunikasi Indonesia Tbk only occurred on day +14 with a sig value. 0.078 . Based on Table 2 , it can be concluded that the effect of the average amount of abnormal returns before and after the announcement event during the observation period from day -15 to day +15 for each period was negative $(-0.001)$. Thus, the hypothesis was accepted. An indication of investors' tendency to react to selling their shares was caused by panic and investors' concerns about the economic conditions when announcing the first case of COVID$19 \mathrm{in} \mathrm{Indonesia.} \mathrm{The} \mathrm{negative} \mathrm{average} \mathrm{abnormal} \mathrm{return} \mathrm{value} \mathrm{from} \mathrm{the} \mathrm{announcement} \mathrm{event} \mathrm{led} \mathrm{to} \mathrm{a} \mathrm{massive}$ sale of shares and decreased wealth.

The paired sample t-test results obtained a sig value (2-tailed) of $0.806>0.05$; thus, it can be concluded that hypothesis II was rejected. This indicates no substantial difference in the average abnormal Return when the first case of COVID-19 was declared in Indonesia on March 2, 2020. The average abnormal return difference within the research period indicates that the situation and circumstances before and after this event contained sufficient information to make the market react. There was a little market reaction to this case, reflecting that market participants learned through experience expecting this incident to ensure 
that they were not in a hurry to carry out share trading activities. Market participants also focused their investment decisions on company performance rather than events that happened. Even though there was a significant change in the company's circumstances, buying and selling shares would be made.

\section{Discussion}

According to the developed hypothesis, the result shows that $\mathrm{H}_{1}$ accepted and $\mathrm{H}_{2}$ rejected. The mean of AAR of the 5 Telco company that registered in the IDX prior the first COVID-19 case in Indonesia is lower than the following announcement. As such, the implication of the research results there is a insignificant or negative impact that announcement gives to the AAR. This is reflected in the stock price, which is still relatively stable after the announcement, meaning that investors cannot distinguish whether information that has economic value or not (Bahloul \& Khemakhem, 2021; Sharma et al., 2021). This reaction shows that investors have preferences that are not much different from other macro event announcements (Papadamou et al., 2021; Sharif et al., 2020). The difference in preferences is due to differences in processing information received by investors from announcements of other events.

In line with the paired samples t-test, there is no significant difference in AAR of the 5 Telecommunications companies registered in IDX between 15 days before (February 10, 2020-March 1, 2020) and 15 days after, the announcement of the first COVID-19 case in Indonesia. Furthermore, the investors should not be concerned and should continue to invest in telecommunications companies because there is no significant difference in AAR following the announcement of COVID-19 case in Indonesia. Telcos' financial performances have remained stable amid the pandemic in accordance with the government advisory. Indonesian telecommunications firms are expected to reap long-term benefits from the coronavirus health crisis due to increasing demand for mobile data and internet connectivity (Ariansyah et al., 2021; Syamsuddin et al., 2021).

Based on the results and analysis before, the Indonesian stock market will treat the COVID-19 pandemic as a national emergency, which is critical information that could affect the share price of the Telecommunication Industry sub-sector companies as a whole. The trend of stock price movement resembles random walks or lacks a standard (Ligot et al., 2021; Lou et al., 2021). Many factors influence whether a market is efficient or inefficient (Ho et al., 2021; Teplova \& Tomtosov, 2021). Market efficiency is affected by precise information. The EMH theory serves as a guide for market participants when developing investment strategies to capitalize on profit opportunities. The extracted information must be discernible to persuade market conditions ultimately. Reflections on trust in companies on the COVID-19 pandemic have relatively decreased. In this case, investors do not get above-normal profits (Dwivedi et al., 2020; Nanda et al., 2021).

Furthermore, no single market actor or a group of market participants may benefit from a market reaction. This result supports a semi-strong efficient market hypothesis, which states that market circumstances react promptly to the public information about COVID-19. According to the study findings, the announcement of the first case of COVID-19 in Indonesia elicited an adverse market reaction, which is in line with research conducted by (Ashraf, 2020; Fauziah \& Venusita, 2021), which revealed that stock markets responded negatively to COVID-19 cases.

\section{CONCLUSION}

Based on the results of testing and analysis of the sample data obtained, several conclusions can be drawn in this study that the Indonesian stock reacts to unexpected events such as announcing the first case of COVID-19 in Indonesia. It is expected that Indonesia's stock market has a different change from its condition before and after the crisis. The finding showed that stocks reacted positively but insignificant to the announcement of the first case in Indonesia by using an event study research design. There is a significant difference in abnormal returns before and after the first case of COVID-19 patients in Indonesia was announced.

\section{REFERENCES}

Ahmad, W., Kutan, A. M., \& Gupta, S. (2021). Black swan events and COVID-19 outbreak: Sector level evidence from the US, UK, and European stock markets. International Review of Economics \& Finance, 75. https://doi.org/10.1016/j.iref.2021.04.007.

Aji, R. H. S. (2020). Dampak Covid-19 pada Pendidikan di Indonesia: Sekolah, Keterampilan, dan Proses Pembelajaran. Jurnal Sosial Dan Budaya Syar-I, 7(5). https://doi.org/10.15408/sjsbs.v7i5.15314.

AlAli, M. S. (2020). The Effect of WHO COVID-19 Announcement on Asian Stock Markets Returns: An Event Study Analysis. Journal of Economics and Business, 3(3). 
https://doi.org/10.31014/aior.1992.03.03.261.

Ali, S. R. M., Mensi, W., Anik, K. I., Rahman, M., \& Kang, S. H. (2021). The impacts of COVID-19 crisis on spillovers between the oil and stock markets: Evidence from the largest oil importers and exporters. Economic Analysis and Policy. https://doi.org/10.1016/j.eap.2021.11.009.

Alonderienè, R., \& Suchotina, N. (2017). The Impact of Self-directed Learning on Work Performance of Lawyers. Organizations And Markets In Emerging Economies, 8(2). https://doi.org/10.15388/omee.2017.8.2.14185.

Ambarita, E. (2021). Belajar Dari Rumah (Bdr) Menggunakan Padlet Alternatif E-Learning Pada Masa Pandemi Covid-19 (Studi Kasus Di Sman 56 Jakarta). JIRA: Jurnal Inovasi Dan Riset Akademik, 2(1), 30-36. https://doi.org/10.47387/jira.v2i1.70.

Ariansyah, K., Sirait, E. R. E., Nugroho, B. A., \& Suryanegara, M. (2021). Drivers of and barriers to e-commerce adoption in Indonesia: Individuals' perspectives and the implications. Telecommunications Policy, 45(8). https: //doi.org/10.1016/j.telpol.2021.102219.

Ashraf, B. N. (2020). Stock markets' reaction to COVID-19: Cases or fatalities? Research in International Business and Finance, 54. https://doi.org/10.1016/j.ribaf.2020.101249.

Asmirantho, E., \& Somantri, O. K. (2017). The Effect of Financial Performance on Stock Price At Pharmaceutical Sub-Sector Company Listed in Indonesia Stock Exchange. JIAFE (Jurnal Ilmiah Akuntansi Fakultas Ekonomi), 3(2). https://doi.org/10.34204/jiafe.v3i2.778.

Bahloul, S., \& Khemakhem, I. (2021). Dynamic return and volatility connectedness between commodities and Islamic stock market indices. Resources Policy, 71. https://doi.org/10.1016/j.resourpol.2021.101993.

Baker, S. R., Bloom, N., Davis, S. J., Kost, K., Sammon, M. C., \& Viratyosin, T. (2020). The Unprecedented Stock Market Impact of COVID-19. Review of Corporate Finance Studies. https://doi.org/10.3386/w26945.

Bash, A. (2020). International Evidence of Covid-19 and Stock Market Returns: an Event Study Analysis. International Journal of Economics and Financial Issues, 10(4). https://doi.org/10.32479/ijefi.9941.

Ben-Ahmed, K., Ayadi, I., \& Hamad, S. Ben. (2021). COVID-19 impact on digital companies' stock return: A dynamic data analysis. Finance Research Letters. https://doi.org/10.1016/j.frl.2021.102340.

Dey, A. K., Hoque, G. M. T., Das, K. P., \& Panovska, I. (2021). Impacts of COVID-19 local spread and Google search trend on the US stock market. Physica A: Statistical Mechanics and Its Applications. https://doi.org/10.1016/j.physa.2021.126423.

Dian, Y. A., Bagus, P., \& Permatasari. (2019). Do Earnings Management and Institutional Ownership Affect Stock Market Liquidity? Opcion, 35(24). https://doi.org/10.1017/ CB09781107415324.004.

Dwivedi, Y. K., Hughes, D. L., Coombs, C., Constantiou, I., \& Duan, Y. (2020). Impact of COVID-19 pandemic on information management research and practice: Transforming education, work and life. International Journal of Information 55. https://doi.org/10.1016/j.ijinfomgt.2020.102211.

Engelhardt, N., Krause, M., Neukirchen, D., \& Posch, P. N. (2021). Trust and stock market volatility during the COVID-19 crisis. Finance Research Letters, 38. https://doi.org/10.1016/j.frl.2020.101873.

Fauziah, L., \& Venusita, L. (2021). The Reaction of Capital Markets in Indonesia, Singapore , Malaysia , and Thailand Towards the Announcement of Lockdown Policy During the Beginning of the Covid-19. Journal of Accounting, Entrepreneurship, and Financial Technology, 2. https: //doi.org/10.37715/jaef.v2i2.1831.

Gandasari, D., \& Dwidienawati, D. (2020). Content analysis of social and economic issues in Indonesia during the COVID-19 pandemic. Heliyon, 6(11). https://doi.org/10.1016/j.heliyon.2020.e05599.

Haryanto. (2020). Dampak Covid-19 terhadap Pergerakan Nilai Tukar Rupiah dan Indeks Harga Saham Gabungan (IHSG). Jurnal Perencanaan Pembangunan: The Indonesian Journal of Development Planning, 4(2). https://doi.org/10.36574/jpp.v4i2.114.

Hincal, E., \& Alsaadi, S. H. (2021). Stability analysis of fractional order model on corona transmission dynamics. Chaos, Solitons \& Fractals, 143, 110628. https://doi.org/10.1016/j.chaos.2020.110628.

Ho, K.-C., Li, H.-M., \& Gong, Y. (2021). How does corporate social performance affect investment inefficiency? An empirical study of China market. Borsa Istanbul Review. https://doi.org/10.1016/j.bir.2021.06.016.

Huang, Y. (2020). Research on Online Education in the Midst of the COVID-19 Pandemic. Journal of Advances in Education Research, 5(2), 125-137. https://doi.org/10.22606/jaer.2020.52005.

Indrawati, M., Prihadi, C., \& Siantoro, A. (2020). The Covid-19 Pandemic Impact on Children's Education in Disadvantaged and Rural Area Across Indonesia. International Journal of Education (IJE), 8(4), 1933. https://doi.org/10.5121/ije.2020.8403.

Ligot, S., Gillet, R., \& Veryzhenko, I. (2021). Intraday volatility smile: Effects of fragmentation and high 
frequency trading on price efficiency. Journal of International Financial Markets, Institutions and Money, 75. https://doi.org/10.1016/j.intfin.2021.101437.

Liu, H., Manzoor, A., Wang, C., Zhang, L., \& Manzoor, Z. (2020). The COVID-19 outbreak and affected countries stock markets response. International Journal of Environmental Research and Public Health, 17(8). https://doi.org/10.3390/ijerph17082800.

Liu, Q., Huang, J., \& Zhou, Z. (2020). Self-expansion via smartphone and smartphone addiction tendency among adolescents: A moderated mediation model. Children and Youth Services Review, 119(June), 105590. https://doi.org/10.1016/j.childyouth.2020.105590.

Lou, J., Wong, T. W., Fung, K. W. T., \& Shaende, J. J. N. (2021). Stock and bond joint pricing, consumption surplus, and inflation news. Research in International Business and Finance, 58. https://doi.org/10.1016/j.ribaf.2021.101426.

Lyócsa, Š., Baumöhl, E., Výrost, T., \& Molnár, P. (2020). Fear of the coronavirus and the stock markets. Finance Research Letters, 36. https://doi.org/10.1016/j.frl.2020.101735.

Lyócsa, Š., \& Molnár, P. (2020). Stock market oscillations during the corona crash: The role of fear and uncertainty. Finance Research Letters, 36. https://doi.org/10.1016/j.frl.2020.101707.

Matos, P., Costa, A., \& Silva, C. da. (2021). COVID-19, stock market and sectoral contagion in US: a timefrequency analysis. Research in International Business and Finance, 57. https://doi.org/10.1016/j.ribaf.2021.101400.

Mpungose, C. B. (2021). Lecturers' reflections on use of Zoom video conferencing technology for e-learning at a South African university in the context of coronavirus. African Identities. https://doi.org/10.1080/14725843.2021.1902268.

Nanda, A., Xu, Y., \& Zhang, F. (2021). How would the COVID-19 pandemic reshape retail real estate and high streets through acceleration of E-commerce and digitalization? Journal of Urban Management, 10(2). https://doi.org/10.1016/j.jum.2021.04.001.

Papadamou, S., Fassas, A. P., Kenourgios, D., \& Dimitriou, D. (2021). Flight-to-quality between global stock and bond markets in the COVID era. Finance Research Letters, 38. https://doi.org/10.1016/j.frl.2020.101852.

Putria, H., Maula, L. H., \& Uswatun, D. A. (2020). Analisis Proses Pembelajaran dalam Jaringan (DARING) Masa Pandemi Covid- 19 Pada Guru Sekolah Dasar. Jurnal Basicedu, 4(4), 861-872. https://doi.org/10.31004/basicedu.v4i4.460.

Ratnaningsih, N. M. D., \& Widanaputra, A. A. G. P. (2019). The reaction of Indonesian capital market to political event the announcement of Indonesia presidential election 2019 results. International Research Journal of Management, IT and Social Sciences, 6(6). https://doi.org/10.21744/irjmis.v6n6.765.

Scherf, M., Matschke, X., \& Rieger, M. O. (2021). Stock market reactions to COVID-19 lockdown: A global analysis. Finance Research Letters. https://doi.org/10.1016/j.frl.2021.102245.

Shah, K., Arfan, M., Mahariq, I., Ahmadian, A., Salahshour, S., \& Ferrara, M. (2020). Fractal-Fractional Mathematical Model Addressing the Situation of Corona Virus in Pakistan. Results in Physics, 19, 103560. https://doi.org/10.1016/j.rinp.2020.103560.

Shahzad, A., Yaqub, R. M. S., Vaio, A. Di, \& Hassan, R. (2021). Antecedents of customer loyalty and performance improvement: Evidence from Pakistan's telecommunications sector. Utilities Policy, 70. https://doi.org/10.1016/j.jup.2021.101208.

Sharif, A., Aloui, C., \& Yarovaya, L. (2020). Pandemi COVID-19, harga minyak, pasar saham, risiko geopolitik, dan perhubungan ketidakpastian kebijakan dalam ekonomi AS: Bukti baru dari pendekatan berbasis wavelet. International Review of Financial Analysis, 70. https://doi.org/10.1016/j.irfa.2020.101496.

Sharma, D., Tiwari, A. K., Jain, M., Yadav, A., \& Erkut, B. (2021). Unconditional and conditional analysis between covid-19 cases, temperature, exchange rate and stock markets using wavelet coherence and wavelet partial coherence approaches. Heliyon, $7(2)$. https://doi.org/10.1016/j.heliyon.2021.e06181.

Simamora, R. M. (2020). The Challenges of Online Learning during the COVID-19 Pandemic: An Essay Analysis of Performing Arts Education Students. Studies in Learning and Teaching, 1(2), 86-103. https://doi.org/10.46627/silet.v1i2.38.

Sintema, E. J. (2020). Effect of COVID-19 on the performance of grade 12 students: Implications for STEM education. Eurasia Journal of Mathematics, Science and Technology Education, 16(7), 1-6. https://doi.org/10.29333/EJMSTE/7893.

Sohrabi, C., Alsafi, Z., O'Neill, N., Khan, M., Kerwan, A., Al-Jabir, A., Iosifidis, C., \& Agha, R. (2020). World Health Organization declares global emergency: A review of the 2019 novel coronavirus (COVID-19). International Journal of Surgery, 76(February), 71-76. https://doi.org/10.1016/j.ijsu.2020.02.034. 
Stalmachova, K., \& Strenitzerova, M. (2021). Impact of the COVID-19 pandemic on employment in transport and telecommunications sectors. Transportation Research Procedia, 55. https://doi.org/10.1016/j.trpro.2021.06.009.

Syamsuddin, I., Irmawati, \& Syafaruddin. (2021). An experimental study of RyO Kit for Covid-19 information sharing in rural islands of Indonesia. ICT Express, 7(3). https://doi.org/10.1016/j.icte.2021.02.002.

Teplova, T., \& Tomtosov, A. (2021). Can high trading volume and volatility switch boost momentum to show greater inefficiency and avoid crashes in emerging markets? The economic relationship in factor investing in emerging markets. The Quarterly Review of Economics and Finance, 80. https://doi.org/10.1016/j.qref.2021.01.018.

Wibowo, A., \& Darmanto, S. (2019). Impact of Quick Count Result of President Election on Stock Prices and Trade Activities in the Indonesian Capital Market. Saudi Journal of Business and Management Studies, 4(6). https://doi.org/10.21276/sjbms.2019.4.6.2.

Yousfi, M., Zaied, Y. Ben, Cheikh, N. Ben, Lahouel, B. Ben, \& Bouzgarrou, H. (2021). Effects of the COVID-19 pandemic on the US stock market and uncertainty: A comparative assessment between the first and second waves. Technological Forecasting and Social Change, 167. https: //doi.org/10.1016/j.techfore.2021.120710. 